\title{
Kalkınma Ajanslarında Merkezi ve Yerel Unsurların Etkisi: Kalkınma Ajanslarının Türkiye Uygulaması Üzerine Bir Değerlendirme
}

\begin{abstract}
Salih Ziya KUTLU*
Mustafa GÖRÜN**

Öz

1970 sonrası dönemde bölgesel kalkınma politikalarının giderek daha popüler bir hal alması, bölge ölçeğinde kurumsallaşma çabalarının ortaya çıkmasına neden olmuştur. Illk olarak 1933 yılında Amerika Birleşik Devletleri'nde kurulan kalkınma ajansları, bu kurumsallaşma çabalarının Avrupa'daki yansıması olarak karşımıza çıkmaktadır. Kamu-özel-sivil işbirliğini yerelde gerçekleştirmeye çalışan ajanların Türkiye'de kurulması ise 2006 yılına rastlamaktadır. Literatür taraması şeklinde oluşturulacak çalışmada, merkeziyetçi yönetim anlayışının hakim olduğu Türkiye'de, temel felsefesi yerel yönetişimi gerçekleştirmek olan kalkınma ajanslarının, idari ve mali yapısı ile işlemlerinde merkezi yönetimin etkisi araştrılacaktır. Bu amaçla Türkiye'de kurulan 26 ajansın idari yapılanması, bütçesi ve Kalkınma Bakanlığı ile olan ilişkisi incelenecektir.

Anahtar Kelimeler: Merkezileşme, Yerelleşme, Kalkınma Ajansı
\end{abstract}

\section{The Impact of Central and Local Elements on Development Agencies: An Evaluation Towards The Practice of Development Agencies in Turkey}

\begin{abstract}
After 1970's, the becoming of regional development policies increasingly more popular has led to the emergence of institutionalized efforts of the region. The development agencies, established first in 1933 in the United States, emerge as a reflection of the institutionalization efforts in Europe. The establishment of agencies in Turkey, which try to make cooperation among public-privatecivil sector in local, coincides in 2006. In the study which will be conducted as a literature survey, it is attempted to analyse the impact of central government on administrative and financial structure and transaction of development agencies of which the basic philosophy is to actualise local governance in Turkey in which the centralized management system is dominated. For this purpose, the administrative structures and budgets of the 26 development agencies, which were established in Turkey, and their relationship with the Ministry of Development will be investigated.

Keywords: Centralization, Decentralization, Development Agency
\end{abstract}

\footnotetext{
Çanakkale Onsekiz Mart Üniversitesi, Sosyal Bilimler Enstitüsü Kamu Yönetimi Anabilim Dalı Doktora Öğrencisi, salihziyakutlu@hotmail.com

** Doç. Dr., Çanakkale Onsekiz Mart Üniversitesi, Biga İktisadi ve İdari Bilimler Fakültesi, Kamu Yönetimi Bölümü, mgorun@comu.edu.tr
} 


\section{GíRiş}

Günümüzde yerelleşme, bölgelerarası rekabet, yönetişim gibi kavramlar yeni kamu yönetimi anlayışının hakim olmaya başladığı 1980 sonrası dönemde giderek daha popüler hale gelmiştir. Ortaya çıkan bu kavramlar yönetim ve kalkınma teorisinde önemli değişikliklere neden olmuşlardır. Bunların en önemlilerinden biride bu kavramların ihtiyacı olan kurumsal yapıyı yansıtan kalkınma ajanslarıdır.

Kalkınma ajansları ilk olarak 1933 yılında Amerika Birleşik Devletleri'nde (ABD) kurulan, II. Dünya Savaşı sonrası ise Avrupa'da yaygın kurum olarak karşılaştı̆ıımız bölgesel kalkınma kuruluşlarıdır. 1970 sonrası yeni bölgesel kalkınma anlayışının benimsendiği bir dönemde bölgelerarası rekabet, dış yatırımları bölgeye çekme, kamu-özel-sivil ortaklı̆̆ı gibi ilkeleri benimseyerek bölgelerin ekonomik ve sosyal anlamda kalkınması için çalışmaktadırlar. Türkiye'de kalkınma ajanslarının kurulması ise 2006 yılına rastlamaktadır.

İngiltere üzerine yaptığı çalışmasında Karasu, ekonomik anlamda merkezi bütçeden aktarılan kaynaklara bağlı olan, il düzeyindeki kuruluşların yetkilerini devralan ve yerelde demokrasinin ifadesi olan il ve ilçe meclislerini zayıflatan kalkınma ajansları politikasını "merkezi olarak yönetilen bölgeselleşme" olarak ifade edildiğini belirtmiştir. Bu anlamda yeni bir tür merkezileşmenin ortaya çıktığını iddia eden Karasu, "kamu gücü ve ayrıcaIıklarına sahip, kamu kaynaklarını kullanan, tüzel kişiliği olan, bütçe ve yönetim usulleri açısından" geleneksel kamu kurumlarından ayrılan yeni tip kurumlar oluşturulduğunu belirtmiştir.

Bu anlamda kalkınma ajansları merkezi yönetime planlama, kaynak dağıtımı ve harcama yapma konusunda önemli avantajlar sağlayan bir kurum olarak karşımıza çıkmaktadır (2009: 28-30). İngiltere'de kurulan kalkınma ajansları genel olarak değerlendirildiğinde; ajansların sadece söylemde yerel kaldığını uygulamada ise merkezi öğelerin hala ağırlığını hissettirdiği söylemek yanlış olmayacaktır.

Türkiye'de ajansların kuruluşundan bu yana geçen zaman düşünüldüğünde ajanslar üzerine genel bir değerlendirme yapılabileceği ifade edilebilir. Bu anlamda çalışmanın temel yaklaşımı kalkınma ajanslarındaki merkezileşme-yerelleşme ikilemine dikkat çekmektir. Karasu'nun da İngiltere'deki ajanslar için ifade ettiği "söylemde yerel olmasına rağmen uygulamada merkezi” (2009: 28) olan yapının Türkiye için geçerliliği sorgulanacaktır. Türkiye gibi merkeziyetçi geleneğin güçlü olduğu bir ülkede yerelleşme ve yönetişim kavramları ekseninde şekillenen bir kurum olan kalkınma ajanslarının, uygulamada bu değerleri ne kadar benimsediği tartışılacaktır.

Bu anlamda çalışma kalkınma ajanslarındaki merkezileşme-yerelleşme ikilemini yansıtacak şekilde ajansların idari yapılarının, mali yapılarının ve Kalkınma Bakanlığının ajansların iş ve işlemleri üzerindeki yetkilerinin incelenmesi üzerine kurgulanmıştır.

\section{MERKEZILEŞME-YERELLEŞME KAVRAMLARI ÜZERINE BİR TARTIŞMA}

Dünya üzerinde, ülkenin bütününde sadece merkeziyetçi yönetim anlayışını ya da sadece yerel yönetim anlayışını benimseyen bir ülkenin varlığı söz konusu değildir. Ülkeler kendi tarihleri, sosyo-ekonomik yapıları ve siyasal sistemlerine uygun olarak farklı yönetim modelleri geliştirmişlerdir. Bu yönetim modellerinin belirlenmesinde öne çıkan temel unsur ise etkin ve verimli bir yönetim sistemi oluşturmak adına merkez ve yerel arasındaki dengeyi sağlamak olmuştur (Parlak, 2014: 8). 
Merkezileşme kavramı; merkezi yönetim, merkeziyetçi yönetim, merkeziyetçilik gibi kavramlarla eş anlamlı olarak kullanılmaktadır. Bu kavramlar ile kararların tamamen merkezden alınması, mali kaynaklarının kullanım yetkisinin merkezde toplanması ve kamu hizmetlerinin bizzat merkez eliyle yerine getirilmesi ifade edilmektedir. Merkeziyetçi anlayışta yukarıda belirtilen eylemler merkez ya da onun hiyerarşik yapısı içinde yer alan taşra birimleri tarafindan gerçekleştirilmektedir (Çevik, 2012: 83). Kısacası merkezileşme kamu gücünün tamamıyla merkezde toplanmasıdır (Eroğlu, 1974: 129).

Merkezi yönetim içinde kamu tüzel kişiliği olarak adlandırılan tek bir tüzel kişilikten söz edilebilir. Merkezi yönetim hizmet sunumunu bakanlık, bakanlıkların başkent ve taşra teşkilatları aracılığıyla yerine getirir. Ancak bu durum devletin parçalı bir yapı gösterdiği anlamına gelmez.

Merkezi yönetiminin bütünlüğü bu organlar arasındaki hiyerarşik bağ ile sağlanır (Gözler ve Kaplan, 2012: 31-32). Devlet yönetiminde merkeziyetçi anlayışın uygulanması bazı olumlu ve olumsuz durumları beraberinde getirmektedir. Merkeziyetçi anlayışın olumlu özelliklerinden söz edilecek olunursa, öncelikle merkeziyetçi anlayış merkezi yönetimin güçlenmesini ve yönetimde bütünlüğün gerçekleştirilmesini sağlar. Ayrıca ülkede bölünemez niteliği olan milli savunma ve diplomasi gibi bazı hizmetlerin merkezi yönetimce görülmesinde de yarar vardır. Bunların yanında merkeziyetçi anlayış sunulan hizmetlerin ülke genelinde dengeli olarak dağıtılmasını ve hizmetlerin yerel etkilerden bağımsız olarak tarafsız şekilde yerine getirilmesini sağlar. Böylece bölgeler arasında dengeli bir kalkınma ve idarenin tarafsızlığı sağlanmış olur (Eryılmaz, 2007: 71-72). Merkezileşmenin olumsuz özellikleri ise hizmet sunumunda bürokrasi ve kırtasiyeciliğe neden olarak gecikmelere yol açması ile hizmetlerin yerel ihtiyaçların belirleyiciliğinde değil karar alma tekelini elinde bulunduran merkezin belirleyiciliğinde sunulmasıdır. Alınan kararlarda halkın söz hakkının olmaması ve merkezi yönetim tarafindan hizmetlerin etkin şekilde yerine getirilememesi, merkeziyetçi anlayışı demokratik ilkelerden uzak hale getirmiş halkın yönetime katılımını engellemiştir (Günday, 2007: 71-72).

Yerelleşme kavramı ise, merkeziyetçi yönetimin olumsuzlarını gidermek ve merkezi yönetimce etkin şekilde yerine getirilemeyen hizmetlerin daha iyi şekilde sunumunu sağlamak için merkezden yerele kaynak ve yetki aktarımı olarak tanımlanabilir. Merkezi yönetimin taşra organları, karar alma yetkisi ve mali olanakları olmasına rağmen, yerel yönetim kurumlarına ihtiyaç duyulmasının nedeni yerel ihtiyaçları daha iyi anlamak ve halka daha yakın olmaktır (Tortop vd., 2008: 108).

Yerel yönetim kurumlarının daha etkin hizmet sunumu sağlayabilmesi için merkezi yönetimden ayrı bir tüzel kişiliğe sahip olması gerekmektedir. Bunun yanında yerel yönetim kurumları her ülkenin kendi siyasal sistemine göre belirli derecede özerkliğe de sahip olmalıdır. Özerklik, Türkiye'deki gibi sadece idari ve mali özerkliği içeren bir yapı olabileceği gibi, ABD örneğinde olduğu gibi siyasal özerliğe varan, daha geniş kapsamlı bir özerkliği de ifade edebilir. Dolaysıyla yerel organlar ayrı tüzel kişiliğe sahip, bağımsız karar alıp bunları uygulayabilen, mali kaynaklara sahip ve bunları özgürce kullanabilen bir yapı olarak karşımıza çıkmaktadır. Ancak ülke yönetiminin parçalı bir yapı olarak görünmemesi için bu kurumlar üzerinde merkezi yönetim tarafindan vesayet denetimi uygulanmaktadır (Gözler ve Kaplan, 2012: 33-34). Merkezileşme kavramının olduğu gibi yerelleşme kavramının da bazı olumlu ve olumsuz özellikleri mevcuttur. 
Yerelleşmenin en büyük yararı özellikle günümüzde giderek daha önemli bir hal almaya başlayan demokrasi kavramıyla uyumlu olmasıdır. Kararların yerel halkın iştiraki ile alınması ve ihtiyaçların yerelde belirlenmesi halkın yönetime katılma konusunda daha istekli olmasına neden olmaktadır. Ayrıca yerelde alınan kararlar merkeziyetçi anlayışta görülen bürokrasi, kırtasiyecilik ve gecikmeleri önleyerek hizmetlerin daha etkin ve verimli olarak yerine getirilmesini sağlamaktadır (Giritli vd., 2008: 196-197). Yerelleşmenin olumsuz özellikleri ise ülke bütünlüğüne zarar verebilmesi, bölgeler arasında sosyo-ekonomik eşitsizliklerin ortaya çıkmasına neden olabilmesi, yerel yönetim organlarının yeterli mali ve teknik imkanlara sahip olmamasından dolayı hizmetlerin aksaması ile yerel unsurların etkisiyle ya da oy kaygısıyla hizmet sunumunun etkin ve adil şekilde gerçekleştirilememesi olarak ifade edilebilir (Ökmen ve Parlak, 2000: 15).

Merkezileşme ve yerelleşme kavramları üzerine yapılan açılamalar değerlendirildiğinde, her iki kavramında kendine has olumlu ve olumsuz özelliklere sahip olduğu görülmektedir. Ayrıca bu iki kavramdan sadece birisinin uygulandığı bir ülke örneği bulmakta oldukça güçtür. Bu anlamda merkezileşme ve yerelleşme kavramları aslında birbirinin alternatifi değil birbirinin tamamlayıcısı olarak değerlendirilebilir.(Ayman Güler, 2011: 281) Kısaca bu iki kavram birbirini dengeleyerek daha etkin ve verimli bir yönetim yapısı ortaya çıkarmaya çalışmaktadır. Ancak 20. Yüzyılın son çeyreğinden itibaren özellikle küreselleşme ve uluslararası kuruluşlarında etkisiyle yerelleşme daha sık karşımıza çıkan bir kavram olmaya başlamıştır. Yerelleşme kavramı özellikle 1973 petrol krizi sonrası giderek daha popüler hale gelen yeni bölgesel kalkınma kavramıyla beraber yaygın olarak kullanılmaya başlanmıştır.

Yeni bölgesel kalkınma yaklaşımı, küreselleşme ile beraber bölgelerin kalkınmada başat rol oynamasını sağlamıştır. Kalkınma anlayışındaki değişim üretim şeklinin değişmesine neden olmuş, post-fordist üretim egemen üretim şekli halini almıştır. Yeni bölgesel kalkınma anlayışı ile bölgelerin ve kentlerin kendi potansiyellerini kullanarak ve güçlü yönlerini ortaya çıkartarak kalkınmaları ve bunu merkezden yerele değil yerel merkeze gerçekleştirmeleri fikri benimsenmiştir.

Birçok yazar tarafindan belirtildiği üzere Türkiye Cumhuriyeti'nde kamu yönetiminin teşkilat yapısı ve işleyişi merkeziyetçi bir anlayışı yansıtmaktadır. Cumhuriyetin ilanıyla beraber sosyal refah anlayışının da etkisiyle devlet büyümüş giderek hantal bir yapı haline gelmiştir (Gözübüyük, 2006: 7-8). 2000 sonrası ise Avrupa Birliği (AB) ile olan iyi ilişkiler, kamu yönetimi literatüründe yeni kamu yönetimi yaklaşımı, yeni bölgesel kalkınma yaklaşımı, yerelleşme, bölgeselleşme, subsidiarite ve yönetişim gibi kavramların ön plana çıkması ülkede zorunlu olarak reform çalışmalarının gerçekleştirilmesine neden olmuştur. Bu reformlardan biri olan ve 2006 yılında 5449 sayılı "Kalkınma Ajanslarının Kuruluşu, Koordinasyonu ve Görevleri Hakkında Kanun" ile kurulmaya başlanan kalkınma ajansları da, merkezileşme- yerelleşme tartışmalarının tam orta noktasında yer almaktadır.

\section{DÜNYADA VE TÜRKIYE'DE KALKINMA AJANSLARI}

Bölgesel kalkınma politikalarının merkezileşmeden yerelleşmeye doğru evrilmesi, yerelde yeni kurumların oluşturulması ihtiyacını ortaya çıkarmıştır. 1930 sonrası dönemde ABD'de, II. Dünya Savaşı'ndan sonra ise Avrupa'da sayısı hızla artan kalkınma ajansları işte bu kurumsallaşma çabalarının bir ürünü olarak karşımıza çıkmaktadır. 


\subsection{Dünyada Kalkınma Ajansları}

Dünya'da kalkınma ajanslarına ilişkin ilk örnek, 1933 yılında ABD'de kurulan Tenennsee Valley Authority (TVA)'dır. II. Dünya Savaşı'nı izleyen dönemde ise Avrupa'nın birçok ülkesinde kalkınma ajansları kurulmaya başlanmıştır (Özmen, 2008: 331). Karasu, ajansların giderek yaygınlaşmasını temel olarak iki nedene bağlamaktadır. Bunlardan ilki, ajansların 20. yüzyılın son çeyreğiyle beraber gelişmeye başlayan yeni kamu yönetimi, özelleştirme, yerellik, katılım ve verimlilik gibi kavramların kurumsal yapısını yansıtması; diğer neden ise $A B^{\prime}$ dir. $A B$ mevzuatının büyük bölümünün yerel/bölgesel yönetimlerle ilgili olması ve bölgesel politikaların gerçekleştirilmesinde özellikle maddi olanakların merkezi hükümet yerine bölgesel yönetimlere sağlanması bunu kanıtlar niteliktedir (Karasu, 2009: 8-9).

Bölgesel Kalkınma Ajansları, kuruldukları ülkelerde farklı örgütlenme biçimlerine, personel yapılarına, finansman kaynaklarına ve statülere sahiptirler. Ancak hemen hepsinin ana hedefleri bölgeye yatırımların çekilmesi, bölgenin tanıtımının sağlanması, finansal yardım, teşvik vb. yollarla bölgenin sosyo-ekonomik gelişimine katkı sağlanması ve bölgede işbirliğinin geliştirilmesidir (Özer, 2007: 395). Kayasü'de ajansların tek ortak özelliğini, sınırları belirlenmiş bir alanın içsel potansiyelinin arttırılması olarak ifade etmiştir (Kayasü vd., 2003: 7). Kalkınma ajanslarına ilişkin farklı tanımlamalar yapılabilecek olsa da, kalkınma ajansları genel olarak "merkezi hükümetlerden bağımsız bir idari yapıda, sınırları çizilmiş bir bölgenin girişimcilik potansiyelini geliştirip canlandırmak ve böylece ekonomik kalkınmaya katkı sağlamak amacıyla kurulmuş ve faaliyetlerini kamunun veya özel sektörün finanse ettiği bir kuruluş" şeklinde tanımlanabilir (Sekizinci Beş Yıllık Kalkınma Planı Bölgesel Gelişme Özel İhtisas Komisyonu Raporu, 2000: s.174).

Ajanslar farklı ülkelerde farklı yasal statülere sahip olsalar da bazı ortak özelliklere sahiptirler. Bu ortak özelliklerden ilki, ajanslar özel hukuka tabi kamu kuruluşu olarak yapılandırılmışlardır. Bunun temel nedeni merkeziyetçi anlayışın neden olduğu kat bürokratik yapılanmayı önlemek ve hızlı karar alıp uygulamaya geçilmesini sağlamaktır. İkinci ortak özellik ajansların teşkilat yapılarına ilişkindir. Ajansların teşkilat yapıları genellikle, kuruldukları bölgenin temsilcilerinden oluşan bir genel kurul, genel kurul içinden ya da farklı yollarla belirlenebilen bir yönetim kurulu ve bir genel sekreterlikten oluşmaktadır.

Dünyadaki örnekler incelendiğinde genel kurul veya yönetim kurulunun ajansın karar organı olduğu görülmektedir. Bu kurulların üyeleri ise ajansın kurulduğu ülkedeki mevzuata göre farklı şekillerde belirlenmektedir. Genel sekreterlik ise ajansın icra organıdır. Yine bunların dışında sekreterlik, daire başkanlığı, müdürlük, çalışma grubu ve komite gibi adlarla başka birimlerin kurulması da mümkündür (Sert, 2012: 131-132). Üçüncü bir ortak özellik ise ajansların finansman yapısıyla ilgilidir. Dünyada ajansların mali kaynaklarının önemli bir bölümünün merkezi yönetimce belirlendiği görülmektedir (Özer, 2012: 45). Avrupa özelinde ise özellikle $A B$ fonlarının ajansların bütçesinde önemli bir yer tuttuğu ifade edilebilir (Tutar ve Demiral, 2007: 70). Hatta Avrupa'daki ajanslar gelir yapılarına göre güçlü ve zayıf olmak üzere ikili bir ayrıma tabi tutulmaktadır. Buna göre mali olanaklarını çeşitlendiren ve yeterli miktarda gelir eden ajanlar güçlü, $A B$ fonlarına bağımlı bir bütçeye sahip olan ajanslar ise zayıf ajanslar olarak ifade edilmektedir (Sert, 2012: 133).

Kalkınma ajanslarına ilişkin yapılan açıklamalar değerlendirildiğinde, ajansların başarısını etkileyen bazı faktörlerin var olduğu dikkat çekmektedir. Bunların başında şüphesiz ajansın mali anlamda yeterli kaynağa sahip olması gelmektedir. 
Ajansların bölgenin temel sektörleri ile ilgili çalışma yapmaları ve üstlendikleri görevlerle orantılı gelire sahip olmaları gerekmektedir. Bir diğer husus ise ajans personeli ile ilgilidir. Ajansın yetkin, bölgeyi tanıyan ve girişimci bir ruha sahip bir personel yapısına sahip olması önemlidir. Son unsur ise ajansın meşruiyetidir. Ajansların hem yerel ölçekte desteklenmesi, özel-sivil sektör aktörlerinin desteğini kazanması hem de merkezi hükümetçe bölgesel kalkınmanın ana unsuru olarak görülmesi gerekmektedir (Berber ve Çelepçi, 2005: 150).

\subsection{Türkiye'de Kalkınma Ajansları}

Türkiye Osmanlı İmparatorluğu döneminden beri bölgeler arası dengesizlik sorunuyla mücadele etmektedir. Cumhuriyetin ilanından günümüze kadar mali teşvik programları, bölgesel proje ve planlar yapılmış olmasına rağmen gerek ekonomik kaynak sıkıntısı gerek kurumsallaşmada yaşanan eksiklikler gerekse bölge kavramına karşı olan olumsuz tavır soruna çözüm bulunamamasına neden olmuştur. 2000 sonrasında ise AB ile olan yakın ilişkiler ülkede yeni bir anlayışın gelişmesine imkan vermiştir.

Türkiye'de kalkınma ajanslarının temeli 2002 yılında oluşturulan NUTS (No-menclature of Territorial Units for Statistics - İstatistiki Bölge Birimleri Sınıflandırması) sınıflandırması ile atılmıştır. NUTS, AB ülkelerindeki bölgelerarası dengesizlikleri gidermek ve geri kalmış bölgelerin $A B$ fonlarından yararlanmasını sağlamak adına oluşturulmuş bir sistemdir. Bununla amaçlanan bölgelere ait verilerin karşılaştrrma yapmaya imkan sağlayacak şekilde toplanması ve bölgelerarası gelişmişlik farklarının belirlenmesidir (Çamur ve Gümüş, 2005: 147).

Türkiye'de de 2000 yılı Illerleme Raporu ve 2001 yılı Katılım Ortaklığı Belgesinde tavsiye edildiği üzere, verilerini $A B$ ile uyumlu bir hale getirmek için il sınırları baz alınarak 81 adet Düzey 3, 26 adet Düzey 2 ve 12 adet Düzey 1 bölgesi oluşturulmuştur. Ajansların kurulmasına ilişkin kanuni altyapı ise 25 Ocak 2006 tarih ve 5449 sayılı "Kalkınma Ajanslarının Kuruluş, Koordinasyon ve Görevleri Hakkında Kanun” ile oluşturulmuştur. Bu kanuna dayanılarak 2006 yılında 2, 2007 yılında 8 ve 2009 yılında 16 olmak üzere toplam 26 Düzey 2 bölgesinde kalkınma ajansları kurulmuştur (Şinik, 2010: 131-132).

5449 sayılı kanuna göre kalkınma ajanslarının amacı; "kamu kesimi, özel kesim ve sivil toplum kuruluşları arasındaki işbirliğini geliştirmek, kaynakların yerinde ve etkin kullanımını sağlamak ve yerel potansiyeli harekete geçirmek suretiyle, ulusal kalkınma plânı ve programlarda öngörülen ilke ve politikalarla uyumlu olarak bölgesel gelişmeyi hızlandırmak, sürdürülebilirliğini sağlamak, bölgeler arası ve bölge içi gelişmişlik farklarını azaltmak" şeklinde ifade edilmiştir (md. 1).

Bu çerçevede ajanslar, kalkınmanın ülke geneline dengeli şekilde dağıtılması ve bölgelerin potansiyellerinin geliştirilerek rekabet güçlerinin arttırılması amacıyla kurulmuşlardır (Kalkınma Bakanlığı Bölgesel Gelişme Ulusal Stratejisi, 2014-2023, s.90). 2006 yılında kabul edilen kanuna göre ajanslar Devlet Planlama Teşkilat koordinasyonunda faaliyetlerini yerine getirmektedir. Ancak 2011 yılında Kalkınma Bakanlığı'nın kurulmasıyla ajanslar bu bakanlığın ilgili kuruluşu olarak faaliyetlerini sürdürmeye devam etmişlerdir. 
Tablo 1: Türkiye'de Kurulan Kalkınma Ajansları

\begin{tabular}{|c|c|c|c|}
\hline Kuruluş & Düzey-2 Bölgesi & Kapsadığı iller & Merkez il \\
\hline \multirow{3}{*}{2006} & TR31 IZKA & İzmir & izMiR \\
\hline & TR62 ÇKA & Mersin, Adana & ADANA \\
\hline & TR10 isTKA & İstanbul & ISTANBUL \\
\hline \multirow{6}{*}{2008} & TR52 MEVKA & Konya, Karaman & KONYA \\
\hline & TR83 OKA & Amasya, Çorum, Samsun, Tokat & SAMSUN \\
\hline & TRA1 KUDAKA & Bayburt, Erzincan, Erzurum & ERZURUM \\
\hline & TRB2 DAKA & Bitlis, Hakkâri, Muş, Van & VAN \\
\hline & TRC1 IKA & Adıyaman, Gaziantep, Kilis & GAZIANTEP \\
\hline & TRC2 KARACADAĞ & Diyarbakır, Şanlıurfa & DIYARBAKIR \\
\hline \multirow{17}{*}{2009} & TRC3 DIKA & Batman, Mardin, Şırnak, Siirt & MARDIN \\
\hline & TR21 TRAKYAKA & Edirne, Kırklareli, Tekirdağ & TEKIRDAĞ \\
\hline & TR22 GMKA & Balıkesir, Çanakkale & BALIKESIR \\
\hline & TR32 GEKA & Aydın, Denizli, Muğla & DENIZLi \\
\hline & TR33 ZEKA & $\begin{array}{l}\text { Afyonkarahisar, Kütahya, } \\
\text { Manisa, Uşak }\end{array}$ & KÜTAHYA \\
\hline & TR41 BEBKA & Bilecik, Bursa, Eskişehir & BURSA \\
\hline & TR42 MARKA & $\begin{array}{l}\text { Bolu, Düzce, Kocaeli, Sakarya, } \\
\text { Yalova }\end{array}$ & KOCAELI \\
\hline & TR51 ANKARAKA & Ankara & ANKARA \\
\hline & TR61 BAKA & Antalya, Burdur, Isparta & ISPARTA \\
\hline & TR63 DOĞAKA & $\begin{array}{l}\text { Hatay, Kahramanmaraş, Os- } \\
\text { maniye }\end{array}$ & HATAY \\
\hline & TR71 AHIKA & $\begin{array}{l}\text { Aksaray, Kırıkkale, Kırşehir, } \\
\text { Nevşehir, Niğde }\end{array}$ & NEVŞEHIR \\
\hline & TR72 ORAN & Kayseri, Sivas, Yozgat & KAYSERI \\
\hline & TR81 BAKKA & Bartın, Karabük, Zonguldak & ZONGULDAK \\
\hline & TR82 KUZKA & Çankırı, Kastamonu, Sinop & KASTAMONU \\
\hline & TR90 DOKA & $\begin{array}{l}\text { Artvin, Giresun, Gümüşhane, } \\
\text { Ordu, Rize, Trabzon }\end{array}$ & TRABZON \\
\hline & TRA2 SERKA & Ağrı, Ardahan, Iğdır, Kars & KARS \\
\hline & TRB1 FKA & Bingöl, Elazığ, Malatya, Tunceli & MALATYA \\
\hline
\end{tabular}

Kaynak: Kalkınma Bakanlığı Kalkınma Ajanları 2010 Yılı Genel Faaliyet Raporu, Ankara 2011, s.13. 
Dünyadaki uygulamalarına benzer şekilde Türkiye'deki ajansların idari yapısı da, ajansın kurulduğu bölgenin kamu-özel-sivil temsilcilerinden oluşan ve danışma organı niteliğinde olan kalkınma kurulu, ajansın karar organı olan yönetim kurulu ve ajansın icracı organı olan genel sekreterlikten oluşmaktadır. Ayrıca yönetim kurulu kararıyla ajansın faaliyet gösterdiği illerde açılabilen yatırım destek ofisleri de kalkınma ajanslarının idari yapılanmasının son unsurunu oluşturmaktadır (5449 Sayılı Kanun, md.7-17).

5449 sayılı Kalkınma Ajanslarının Kuruluş, Koordinasyon ve Görevleri Hakkında Kanun'un 5. maddesinde Kalkınma Ajanslarının görev ve yetkileri sıralanmıştı. Kalkınma ajanslarının çalışma konusu ile ilgili görevleri şu şekilde sıralanabilir (5449 Sayılı Kanun, md.5); ${ }^{1}$

“a) Yerel yönetimlerin plânlama çalışmalarına teknik destek sağlamak.

b) Bölge plân ve programlarının uygulanmasını sağlayıcı faaliyet ve projelere destek olmak; bu kapsamda desteklenen faaliyet ve projelerin uygulama sürecini izlemek, değerlendirmek ve sonuçlarını Devlet Planlama Teşkilat Müsteşarlı̆̆ına bildirmek.

d) Bölgede kamu kesimi, özel kesim ve sivil toplum kuruluşları tarafindan yürütülen ve bölge plân ve programları açısından önemli görülen diğer projeleri izlemek.

e) Bölgesel gelişme hedeflerini gerçekleştirmeye yönelik olarak; kamu kesimi, özel kesim ve sivil toplum kuruluşları arasındaki işbirliğini geliştirmek.

g) Bölgenin kaynak ve olanaklarını tespit etmeye, ekonomik ve sosyal gelişmeyi hızlandırmaya ve rekabet gücünü artırmaya yönelik araştırmalar yapmak, yaptırmak, başka kişi, kurum ve kuruluşların yaptığı araştırmaları desteklemek.

i) Bölge illerinde yatırımcıların, kamu kurum ve kuruluşlarının görev ve yetki alanına giren izin ve ruhsat işlemleri ile diğer idarî iş ve işlemlerini, ilgili mevzuatta belirtilen süre içinde sonuçlandırmak üzere tek elden takip ve koordine etmek.

j) Yönetim, üretim, tanıtım, pazarlama, teknoloji, finansman, örgütlenme ve işgücü eğitimi gibi konularda, ilgili kuruluşlarla işbirliği sağlayarak küçük ve orta ölçekli işletmelerle yeni girişimcileri desteklemek.

k) Türkiye'nin katıldığı ikili veya çok taraflı uluslararası programlara ilişkin faaliyetlerin bölgede tanıtımını yapmak ve bu programlar kapsamında proje geliştirilmesine katkı sağlamak."

Kalkınma ajanslarının mevcut teşkilat yapısı ve kendilerine verilen görevler düşünüldüğünde kalkınma ajanslarından yerel aktörler arasında bir sinerji oluşturmak, yerel kaynakların etkin kullanılmasını sağlamak, bölgenin planlama ve proje üretme kapasitesini geliştirmek ve böylece hem bölgesel hem de ulusal kalkınmaya yardımcı olmak gibi beklentiler mevcuttur (Göymen, 2010: 159). 2006 yılında Kalkınma Ajanslarına ilişkin mevzuatın hazırlanmaya başlanmasıyla birlikte geçen 10 yıllık süre düşünüldüğünde, kalkınma ajansları kendilerinden beklenen gelişimi henüz kaydedebilmiş sayılmazlar.

15449 sayılı Kalkınma Ajanslarının Kuruluş, Koordinasyon ve Görevleri Hakkında Kanun'un 5. maddesinde yer alan c, f, h ve I bentleri çalışmanın içeriği dışında olduğu için yer verilmemiştir. 
Bu anlamda kalkınma ajanslarının Türkiye'deki uygulaması birçok noktadan eleştirilere konu olmuştur. Bu eleştiriler (Efe, 2016: 109);

- Ajansların tek tip bir yapılanmaya sahip olması,

- Bölgelerin belirlenmesinde gerçekleştirilen hatalar,

- Kalkınma kurullarının etkisizliği,

- Yönetim kurullarının düzenli toplanamaması,

- Kalkınma Bakanlığı'nın ajanslar üzerindeki ağır vesayeti,

- Bölge aktörleri arasındaki yetersiz işbirliği,

- Bölge planı hazırlama sürecindeki olumsuzluklar,

- Ajansların yeterli veri toplayamaması ve güvenilir verilere ulaşamaması,

- Ajansları mali denetim ve performans denetimlerinde yaşanan sorunlar,

- İç denetçi istihdamında yaşanan sorunlar,

- Dış denetimde, özellikle Sayıştay denetimine karşı duyulan hassasiyet,

- Kalkınma Bakanlığı ve Kalkınma Ajansları arasındaki ilişkin hesap verebi-

lirlik adına olumsuz yönlere sahip olması şeklinde sıralanabilir.

Karasu'da benzer şekilde ülkenin bütün bölgelerinde ve aynı örgütlenme özelliklerine sahip ajans yapılanmalarının varlığını eleştirmiştir. Hatta sadece aynı ülke içinde değil farklı ülkelerde kurulan bazı ajansların bile benzer yapıda olduğunu belirtmiştir (2015: 281). Tek tip örgütlenme probleminin yanında ajansların politikalarını belirleyen vizyon, misyon, strateji belgeleri gibi bildirimleri incelendiğinde de ajanların benzer ve yüzeysel ifadelere yer verdikleri görülmektedir (Emini ve Görün, 2013: 101). Açıkçası bu durum bölgelerin özgünlüğü ile çelişen bir yapıyı işaret etmektedir.

\section{MERKEZILEŞME-YERELLEŞME IKILEMINDE KALKINMA AJANSLARI: KALKIN- MA AJANSLARININ TÜRKIYE UYGULAMASI ÜZERINE BIR DEĞERLENDIRME}

Dünyada ve Türkiye'de faaliyet gösteren kalkınma ajanslarına ilişkin açıklamalar, teori ve uygulama arasındaki farkların sorgulanmasını gerekli kılmaktadır. Öyle ki kalkınma politikalarının yerelde kamu-özel-sivil ortaklığı ve idari-mali özerkliğe sahip kurumlar olarak dizayn edilmiş kalkınma ajansları tarafından belirlenmesinin ne derecede gerçekleştiğinin saptanması bu açıdan önemlidir. Çalışmanın bu bölümünde Türkiye'de kuruluşlarının üzerinden 10 yıl geçen kalkınma ajansları üzerinde teşkilat yapısı, bütçe, iş ve işlemleri gibi ölçütler kullanılarak, ajanların merkezileşme yerelleşme tartışmalarındaki konumu belirlenmeye çalışılacaktır.

\subsection{Kalkınma Ajanslarının Teşkilat Yapısının Merkezileşme-Yerelleşmeye Etkisi}

Kalkınma ajanslarının teşkilat yapısı daha öncede belirtildiği üzere Kalkınma Kurulu, Yönetim Kurulu, Genel Sekreterlik ve Yatırım Destek Ofislerinden oluşmaktadır. Ajansların bu teşkilat yapısı kanunla belirlenmiştir. Ve tüm ajanslarda aynı şekilde uygulanmaktadır.

Kalkınma Kurulu, kalkınma ajanslarında yerelleşme ve yönetişim kavramlarını en iyi yansıtan kurum olarak ifade edilebilir. Kalkınma kurulu, bölgedeki kamu kurum ve kuruluşları, özel kesim, sivil toplum kuruluşları, üniversiteler ve yerel yönetimler temsilcilerinden oluşmaktadır. Kurulun temel amacı üyesi olan aktörler arasında işbirliğini geliştirmek ve ajansı yönlendirmektir (5449 sayılı Kanun, md. 8). Bu anlamda kalkınma kurulu ajansın danışma organı olarak ifade edilebilir (Kalkınma Ajansları 2012 Yılı Faaliyet Raporu, 2013: s.25). 
Kalkınma kurulu ajansın kapsadığı illerin dengeli şekilde temsilini sağlayacak şekilde oluşturulur. Üye sayısı en fazla 100'dür. Ancak bu üyelerin kimler olduğu kuruluş kararnamesi yani bakanlar kurulu tarafindan belirlenir. Kurul yılda en az iki defa toplanır. Toplant yetersayısı üyelerin yarısından bir fazla (51), karar yetersayısı ise toplantiya katılanların yarısından bir fazla (26)'dır. İlk toplantıda toplant yetersayısı sağlamaz ise 15 gün içinde ikinci bir toplant gerçekleştirilir ve burada toplant yetersayısı aranmaz. Kalkınma kurulunun görevleri; “a) Tek ilden oluşan bölgelerde yönetim kurulunda yer alacak özel kesim ve/veya sivil toplum kuruluşları temsilcilerini ve iki kat yedeklerini sırasıyla seçmek. b) Ajansın yıllık faaliyet ve iç denetim raporlarını görüşmek, değerlendirmek ve yönetim kuruluna önerilerde bulunmak. c) Bölgenin sorunlarına ve çözüm önerilerine, tanıtımına, potansiyeline ve önceliklerine yönelik olarak yönetim kuruluna tavsiyelerde bulunmak. d) Toplantı sonuçlarını Devlet Planlama Teşkilatı Müsteşarlığına raporlamak ve toplantyya ilişkin bir sonuç bildirisi yayımlamak"tır (5449 sayılı Kanun, md. 8-9).

Kalkınma ajansının idari yapılanması içinde, ajansın yönetişim ve yerelleşme felsefesini en iyi yansıtan organ olan kalkınma kurulu, daha çok tavsiye ve danışma görevlerini yerine getirmektedir. Kurul bu yönüyle diğer kamu kurumlarında görülmeyen ve yeni bir yapıyı temsil etmektedir. Ancak kurulun bu özelliği aynı zamanda sıklıkla eleştirilere maruz kalmasına da neden olmuştur. 100 üyeden oluşan Kalkınma Kurulunun karar yetkisinin bulunmaması, kurulun etken olmayan bir yapı olarak görülmesine neden olmuştur (Akgül, 2010: 648-652).

Kalkınma kurulunun en önemli görevi ise tek ilden oluşan ajanslarda yönetim kurulunda yer alacak, özel sektör veya sivil toplum kuruluşu temsilcilerini seçmektir. Bu şekilde yönetim kurulunun yerel unsurları yine yerel unsurlardan oluşan bir kurul aracılığıyla seçilmiş ve yönetim kurulu kararları kısmen de olsa yerel aktörlere açılmış olmaktadır. Bu durum yönetişim, yerelleşme ve katlım açısından önemli unsur olarak göze çarpmaktadır.

Kalkınma kuruluna ilişkin ele alınabilecek bir diğer husus ise kurulu oluşturan 100 üyenin belirlenme yöntemidir. Yasada bu hususun kuruluş kararnamesi ile belirleneceği ibaresi yer almaktadır (5449 sayılı Kanun, md. 8). İlgili kararnameler incelendiğinde kalkınma kurulu üyeliklerinin il bazında; "illerin toplam üye sayıları, iki ilden oluşan Düzey 2 bölgeleri için 25, üç ilden oluşan Düzey 2 bölgeleri için 20, dört ilden oluşan Düzey 2 bölgeleri için 15, beş ve altı ilden oluşan Düzey 2 bölgeleri için 10 üye taban olarak kabul edilmek ve geriye kalan üye sayısı, illerin 2008 yılı Adrese Dayalı Nüfus Kayıt Sistemi sonuçları doğrultusunda bölgedeki nüfus oranlarına göre dağıtılmak suretiyle" belirlenmiştir. Üyelerin kamu-özel-sivil sektörler arasındaki dağılımı ise, kurumların il içerisindeki etkileri, etkinlikleri, üye sayıları, misyonları, ili temsil etme kabiliyetleri ve bölgenin kalkınmasına sağlayacakları katkı gibi unsurlar göz önüne alınarak il valisinin görüşleri neticesinde belirlenmektedir (Resmî Gazete, Bakanlar Kurulu Kararı, Sayı: 27299, md. 3).

Kalkınma kurulu üyeliğinin il bazında dağıtımında nüfus gibi nesnel bir kriter kullanılmış olmasına rağmen, sektörel dağılımın valinin görüşüne bırakılması ve bunun hiçte nesnel olmayan kriterler ile yapılacak olması kurulun özerkliğini zedeleyici bir husus olarak ifade edilebilir. Ayrıca üyeliklerin bakanlar kurulu kararıyla belirlenmesi ve yine bakanlar kurulu kararıyla yenilenebilmesi/değiştirilebilmesi yerelliği zedeleyici bir nokta olarak karşımıza çıkmaktadır. 
Kalkınma ajansı idari yapılanması içinde, her şeye rağmen, yönetişim felsefesini en iyi şekilde yansıtan organ kalkınma kuruludur. Bunun en önemli göstergelerinden biri açıkıı, şeffafık ve hesap verebilirlik ilkelerini yansıtacak şekilde kurul toplant tutanaklarının her ajansın web sitesi üzerinden erişilebilir olmasıdır.

Bu durum yerellik adına gayet önemli olarak görülebilir. Ancak kalkınma kurulu toplantılarının yılda 2 kez gerçekleştiriliyor olması bir sorun alanı yaratmaktadır. Öyle ki üyeleri 4 yıl görev yapan ve yılda 2 kez toplanan kalkınma kurulunun, ajansı yönlendirme kapasitesinin ne kadar olacağı tartışılmaya değer bir konudur. Ayrıca kalkınma kurulunun karşısında teknik bilgiye, ekonomik ve beşeri imkanlara sahip yönetim kurulu ve genel sekreterlik yer almaktadır. Bu durumda sadece danışma görevi olan bu kurulun taleplerinin ne kadar dikkate alınacağı bir başka tartışma konusu olarak karşımıza çıkmaktadır.

Buna benzer bir görüş Güney Marmara Kalkınma Ajansı 2009 Yılı 2. Olağan Kalkınma Kurulu Toplantısı'nda da dile getirilmiştir. Toplantıda geniş katılımlı bir yapı olan kalkınma kurulunun, yılda 2 kez toplanarak ajansın politikalarına yön vermek, yönetim kuruluna ve genel sekretere önerilerde bulunmak gibi işlevleri yerine getiremeyeceği ifade edilmiştir (Güney Marmara Kalkınma Ajansı 2009 Yılı 2. Olağan Kalkınma Kurulu Toplantısı Sonuç Bildirgesi).

Kalkınma kurullarıyla ilgili olarak değinilecek son durum ise kalkınma kurulu toplantlarına katılım sorunudur. Bu durum, 2014 yılında Devlet Denetleme Kurulu tarafindan hazırlanan "Türkiye'nin Kalkınma Ajansları Uygulamasının Değerlendirilmesi” başlıklı raporun sonuç bölümünde; toplantılara katılım oranının çok düşük kaldığı ve yıllar itibariyle de düşüş eğilimi göstererek devam ettiği, toplantılara katılmama durumu açısından kamu-özel-sivil sektörler arasında bir ayrım olmadığı ifade edilmiştir.

Bazı kurulların yasada belirtilen yılda en az 2 defa toplanma şartını bile yerine getirmedikleri ifade edilmiştir (Devlet Denetleme Kurulu, Türkiye'nin Kalkınma Ajansları Uygulamasının Değerlendirilmesi (Hizmete Özel), 2014: 779). Aşağıdaki tablo, kalkınma kurullarının 2014 ve 2015 yıllarında gerçekleştirdikleri toplantıların katılım miktarlarını içermektedir.

Tablo, 26 ajansın kalkınma kurulu toplant tutanakları incelenerek oluşturulmuştur. Ancak birçok ajans bu toplant tutanaklarında "toplant çoğunluğu sağlanmaktadır" vb. ifadelere yer vermiştir. Bu nedenle sağlıklı verilerin toplanabildiği ajanslar tercih edilerek tabloya dahil edilmiştir. Devlet Denetleme Kurulunun raporuna benzer şekilde, aşağıdaki tabloda da toplant katılımın düşük olduğu görülmektedir. Kalkınma kurulu toplantılarına katılım miktarının 70 kişinin üzerine çıktı̆ı çok az örneğe rastlanmaktadır.

Üye katılımının yüksek olduğu bu toplantıların bazıları ise kalkınma kurulu yönetiminin seçileceği seçimli toplantılardan oluşmaktadır. Örneğin 2014 yılının ilk toplantısında Kalkınma Kurulu Başkanını seçen Serhat Kalkınma Ajansı (SERKA)'nın, toplantılarındaki katilım oranı giderek düşmüştür. 
Tablo 2: Kalkınma Kurulu Toplantıları Katılım Miktarları 2014-2015

\begin{tabular}{|c|c|c|c|c|c|}
\hline \multirow[t]{3}{*}{ Düzey-2 Bölgesi } & \multirow[t]{3}{*}{ Kapsadığı İller } & \multicolumn{4}{|c|}{ Tarih } \\
\hline & & \multicolumn{2}{|c|}{2014} & \multicolumn{2}{|c|}{2015} \\
\hline & & 1. & 2. & 1. & 2. \\
\hline KUDAKA & Bayburt, Erzincan, Erzurum & 55 & - & 65 & - \\
\hline İKA & Adıyaman, Gaziantep, Kilis & 52 & 52 & 52 & 52 \\
\hline DIKA & Batman, Mardin, Şırnak, Siirt & 70 & 69 & 63 & 54 \\
\hline TRAKYAKA & Edirne, Kırklareli, Tekirdağ & 62 & 52 & - & 88 \\
\hline ZEKA & $\begin{array}{l}\text { Afyonkarahisar, Kütahya, } \\
\text { Manisa, Uşak }\end{array}$ & 55 & 75 & 63 & 64 \\
\hline BEBKA & Bilecik, Bursa, Eskişehir & - & - & - & 70 \\
\hline MARKA & $\begin{array}{l}\text { Bolu, Düzce, Kocaeli, Sakarya, } \\
\text { Yalova }\end{array}$ & 62 & - & - & - \\
\hline BAKA & Antalya, Burdur, Isparta & 65 & 70 & 67 & 55 \\
\hline ORAN & Kayseri, Sivas, Yozgat & 81 & 85 & 71 & 75 \\
\hline BAKKA & Bartın, Karabük, Zonguldak & 52 & 51 & - & 54 \\
\hline KUZKA & Çankırı, Kastamonu, Sinop & 63 & 54 & 66 & - \\
\hline SERKA & Ağrı, Ardahan, Iğdır, Kars & 86 & 54 & 65 & - \\
\hline
\end{tabular}

Kaynak: KUDAKA, IKA, TRAKYAKA, DIKA, ZEKA, BEBKA, MARKA, BAKA, ORAN, BAKKA, KUZKA, SERKA Kalkınma Ajansları 2014-2015 yıllarında gerçekleştirilen Kalkınma Kurulu toplantı tutanaklarından derlenmiştir.

Yönetim Kurulu, kalkınma ajansının karar organıdır. Kurul "tek ilden oluşan bölgelerde vali, büyükşehir belediye başkanı, il genel meclisi başkanı, sanayi odası başkanı, ticaret odası başkanı ile kalkınma kurulu tarafindan özel kesim ve/veya sivil toplum kuruluşlarından seçilecek üç temsilciden; birden fazla ilden oluşan bölgelerde il valileri, büyükşehir belediye başkanları veya büyükşehir olmayan illerde il merkez belediye başkanları, il genel meclisi başkanları ve her ilden birer kişi olmak kaydıyla ticaret ve sanayi odası başkanlarından oluşur." Yönetim kurulunun başkanı validir ve başkan ajansı temsil etmektedir. Birden çok ili kapsayan ajanslarda başkanlık görevi birer yıllık sürelerle il valilerince yerine getirilir. Tek ilden oluşan ajanslarda ise kalkınma kurulunca belirlenen üyelerin görev süresi ise 2 yıldır. Bu süre sonunda üyelikler yenilenir. Yönetim kurulu ayda en az 1 defa toplanarak kararlar alır. Alınan kararlar için yapılan oylamada eşitlik olması halinde başkanın oyu yönünde karar verilir (5449 sayılı Kanun, md. 10,11).

Kalkınma Ajanslarının yönetim kurulu yapılanması, kalkınma kurulu yapılanmasında olduğu gibi kamu-özel ortaklığını gerçekleştirecek biçimde oluşturulmuştur. Ancak kurulda kamuyu temsil eden ve merkezi yönetim hiyerarşisi içinde yer alan valinin, ajansın başkanı olması yerelleşme açısından olumsuz bir durumu yansıtmaktadır. Ayrıca yönetişim kavramı bir ilişki ağı olarak düşünüldüğünde, toplumsal aktörlerin bir merkez ya da baskı oluşturan bir aktör olmadan işbirliği ve uzlaşma kültürü içinde karar alabilmeleri ifade edilmektedir (Bayramoğlu, 2010: 147-148). Bu anlamda valinin yönetim kurulundaki konumu sorgulanır bir hal almaktadır. 
Birden fazla ili kapsayan ajanslarda yönetim kurulunda birkaç valinin yer alması, kurulda kamunun egemenliğini arttrır niteliktedir. İlin en yüksek idari amirinin bulunduğu bir kurulda kararların ne derece tarafsız alınabileceği tartışmaya değer bir konudur. Ayrıca yine birden fazla ili kapsayan ajanslarda valilerden birinin başkan diğerinin başkan vekili olarak belirlenmesi de "eşitler arasında birinci" olarak ifade edilebilecek bir durum yaratmaktadır. En az üç ilden oluşan ajanslarda ise valilerden 1'inin yalnızca üye olması ise daha karışık bir duruma işaret etmektedir. Yönetim kurulu ile ilgili olarak ifade edilebilecek bir başka olumsuz durum ise işlemlerinin büyük bir kısmının Kalkınma Bakanlığı'nın onayına tabi olmasıdır. Bu durum yönetim kurulunu daha çok ara kararlar alan bir yapıya büründürerek esnek, katılımcı, hesapverebilir bir organ olmaktan uzaklaştırmaktadır (Devlet Denetleme Kurulu, Türkiye'nin Kalkınma Ajansları Uygulamasının Değerlendirilmesi (Hizmete Özel), 2014: 779-780). Bu durum hala yönetimden çok aktörlü yönetişim anlayışına tam anlamıyla geçilemediğini ve bürokratik yapının olumsuzluklarının devam ettiğini göstermektedir.

Yönetim kurulunun yapısı 6360 sayılı yasa ile önemli bir değişikliğe uğramıştır. Bu yasa ile büyükşehirlerde il özel idarelerinin kapatılması yönetim kurulu yapısının merkezileşmesine neden olmuştur. Bir yerel yönetim organı olan il özel idarelerini kalkınma ajansı yönetim kurulunda temsil eden il genel meclisi başkanlarının üyelikleri de bu yasayla düşmüş olmaktadır. Böylece, ajans yönetiminde biçimsel olarak yerel yönetimler güçsüzleşirken, valinin etkisi arttılıarak merkeziyetçi anlayış güçlendirilmektedir. Karasu, Güney Ege Kalkınma Ajansı'ndaki değişimi örnek vererek, ajansın kapsadığı 3 ilin de (Aydın, Denizli, Muğla) büyükşehir olmasıyla daha önce 3 vali, 6 yerel yönetim temsilcisi ve 3 oda başkanından oluşan yönetim kurulunun, 6360 sayılı kanunla getirilen değişikliklerle 3 vali, 3 yerel yönetim temsilcisi ve 3 oda başkanından oluşmaya başladığını ifade etmiştir (Karasu, 2015: 282-283). Kalkınma ajansları yönetim kuruluna ilişkin olarak ifade edilebilecek bir başka husus ise toplantıları ile ilgilidir. 5449 sayılı yasada yönetim kurullarının en az ayda 1 kez toplanmaları kararı yer almaktadır. Ancak 26 ajansın web siteleri incelediğinde yönetim kurulu toplantıları ve kararlarına ilişkin bir tutanak yer almamaktadır. Bu toplantlara ilişkin bilgiler daha çok ajansların web sitelerinin duyurular ya da haberler adını taşıyan bölümlerinde genel bilgi niteliğinde yer almaktadır. Oysaki kamu-özel işbirliğini yansıtan yönetim kurullarının kararlarının halka açık şekilde alınması, tüm paydaşların sürece dahil edilmesi ve ajansın karar organında uzlaşmacı bir anlayışın var olması yönetişimin gereğidir. Sorumluluk, hesap verebilirlik, şeffaflık, katılımcılık ve yerindenlik gibi yönetişim ilkeleri göz önüne alındığında, böyle bir durumun yönetişim açısından önemli bir sorun alanı olacağı açıktır (Toksöz, 2008: 17-18).

Genel Sekreter, kalkınma ajansının icra organıdır. Genel sekreterliğin ve yatırım destek ofislerinin en üst amiridir ve yönetim kuruluna karşı sorumludur. Genel sekreter yönetim kurulu tarafindan belirlenir ve belirlenen isim Kalkınma Bakanlığı onayı ile göreve başlamaktadır. Ayrıca Kalkınma Bakanlığının genel sekreteri re'sen görevden alma yetkisi de bulunmaktadır. Genel sekreterin görevleri yasayla belirlenmiş ve bunların dışında yönetim kurulunun kendisine verdiği görevleri yerine getirmekle sorumlu tutulmuştur (5449 sayılı Kanun, md.12-14). Genel sekreterin her ne kadar yönetim kurulu aracılığıyla belirleniyor olsa da merkezi bir kurum olan Kalkınma Bakanlığı onayı ile göreve başlıyor olması ve yine bakanlıkça görevden alınabilmesi ajanların yerel olma felsefesi açısından önemli bir sorun olarak ifade edilebilir. 
Ayrıca genel sekreterin kamu-özel-sivil ortaklığını yansıtan ve yönetişim anlayışı ile oluşturulan kalkınma kuruluna karşı değil yönetim kuruluna karşı sorumlu olması da genel sekreterin yerel intiyaçlara kayıtsız kalması sonucunu doğurabilmektedir. Dolayısıyla genel sekreterin sadece yönetim kurulu üyeleri ile ilişkileri sayesinde görevde kalabileceği ve bu durumun liyakat ilkesi açısından bir sorun oluşturabileceği ifade edilebilir.

Kalkınma Ajanslarının idari yapısının temel yapı taşları olan Kalkınma Kurulu, Yönetim Kurulu, Genel Sekreterlik ve Yatırım Destek Ofisleri dışında önemli bir görevi icra eden bir diğer unsur ise iç denetçidir. Kalkınma ajanslarında iç ve dış denetim yapılmaktadır. İç denetim ajansların faaliyetleri, hesapları, işlemleri ve performansını içerecek şekilde gerçekleştirilir. İç denetim faaliyeti yönetim kurulu başkanı veya genel sekreter ile bir iç denetçi tarafindan gerçekleştirilir. Denetim sonunda hazırlanacak raporlar yönetim kuruluna ve kalkınma kuruluna sunulmaktadır (5449 sayılı Kanun, md.25). Yeni Kamu Yönetimi anlayışı ve yönetişim felsefesi çerçevesinde şekillenen bir kurum olan kalkınma ajanslarında performans, etkinlik, verimlilik, katıım, açıklık ve şeffaflık önemli birer ilke olarak karşımıza çıkmaktadır. Bu ilkelerin gerçekleştirilmesi ise ancak denetimle mümkün olmaktadır (Tek Turan, 2013: 65). Ancak bu iç denetim yapısı ajansların denetiminde çeşitli sorunlar yaratmaktadır. Öyle ki ajansın icra organı olan genel sekreterin denetim faaliyetinde bulunması ve yönetim kurulu başkanı olan valinin il ile işlerinin yoğunluğu nedeniyle denetim faaliyetine etkin katılabilme sorunu yaşaması denetim konusunda önemli bir eksikliğin olduğunu göstermektedir. Bunun yanında 2014 yılı itibariyle, 26 kalkınma ajansının sadece 13'ünün iç denetçi istihdamı yapmış olması da denetim konusunda yaşanan sıkıntının büyüklüğünü göstermektedir (Devlet Denetleme Kurulu, Türkiye'nin Kalkınma Ajansları Uygulamasının Değerlendirilmesi (Hizmete Özel), 2014: 791-792).

Kalkınma ajanslarının idari yapılanmasına ilişkin genel bir değerlendirme yapacak olursak, "güçsüz kalkınma kurulu, güçlü vali ve genel sekreter" yapılanmasının yerelleşme, yerel kalkınma ve yönetişim gibi kavramların giderek önem kazandığı bir dönemde merkeziyetçi bir anlayışı yansıttı̆ını ifade etmek yanlış olmayacaktır (Görmez ve Eroğlu, 2013: 15).

\subsection{Kalkınma Ajanslarının Mali Yapısının Merkezileşme-Yerelleşmeye Etkisi}

Kalkınma ajanslarının teşkilat yapısı ve bunun yarattı̆ı sorun alanlarının yanı sıra, ajansların merkezileşme-yerelleşme boyutuyla incelenmesinde mali yapıya da değinmek gereklidir. Çünkü ajansların etkin ve verimli bir hizmet sunması, idari ve mali anlamda özerkliğin varlığına bağlıdır. Yeni kamu yönetimi anlayışının gerektirdiği esnek ve hızlı hizmet sunumu ve yönetişim felsefesinin gerektirdiği katılımcı karar alma mekanizmalarının işlerliği ancak bu özerkliğin varlığı sonucu ortaya çıkacaktır.

Daha öncede belirtildiği üzere hizmetlerin etkin ve verimli bir şekilde sunumu için savunulan yerelleşme kavramı, merkezi yönetim dışında örgütlenmiş bir yapı ortaya çıkarmaktadır. Bu yapıların, her ülkenin kendi idari sistemi içinde değişen seviyede özerkliği mevcuttur. Türkiye Cumhuriyeti Anayasasında da bu organlara idari ve mali özerklik verilmiştir. Genel bir tanımlamayla mali özerklik kuruluşların serbestçe harcama yapabilecekleri kaynaklara sahip olmasıdır (Derdiman, 2007: 68). Mali olanakların yetersizliği ya da mali anlamda merkezi yönetimin sunduğu imkanlara bağlılık bu kuruluşların özerk yapılarına zarar vermektedir (Tortop, 1996: 14-15). Özellikle Türkiye gibi üniter yapılı ülkelerde merkezi yönetimin büyük vergi gelirleri aracılığıyla gelirleri merkezileştirmesi, yerelleşme ilkesi neticesinde ortaya çıkan kuruluşların mali anlamda merkeze bağlı kalmasına neden olmaktadır (Öncel, 1998: 26). 
Kalkınma ajanlarının gelirleri; genel bütçeden, il özel idarelerinden, belediyelerden, sanayi ve ticaret odalarından aktarılan paylar ve diğer ( $A B$ ve diğer uluslararası fonlardan sağlanacak kaynaklar, Faaliyet gelirleri, Ulusal ve uluslararası kurum ve kuruluşlarca yapılan bağış ve yardımlar ile bir önceki yıldan devreden gelirler) gelirlerden oluşmaktadır. Bakanlar kurulu il özel idareleri ve belediyelerden alınacak payları yasada belirtilen oranlar dahilinde yükseltmeye ve indirmeye yetkilidir (5449 sayılı Kanun, md.19). Bu madde kalkınma ajanslarının değil ancak il özel idareleri ve belediyelerin mali özerkliğini zedeleyici bir anlam taşımaktadır.

Ajansların ekonomik yapılarına ilişkin veriler, 2009 sonrası 26 ajansından kuruluş sürecini tamamlayıp faaliyete geçmesinden dolayı 2010 yılından itibaren incelenmiştir. 2010 yılı içinde ajansların bütçe gerçekleşme oranı \%76 düzeyindedir. Gerçekleşme düzeyi en yüksek olan gelir kalemi (\%105) aynı zamanda miktar olarak en düşük gelir kalemi olan sanayi ve ticaret odasından ayrılan paylardır. Bunun dışında genel bütçeden aktarılan paylar \%98 ve il özel idarelerinden aktarılan paylar ise \%96'lık gerçekleşme oranına sahiptir. Gerçekleşme oranı en düşük gelir kalemi ise \%45'le belediyelerdir.

Bütçe gerçekleşme oranının düşük kalmasının sebebinin belediyelerden kaynak tahsil etmekte yaşanılan sıkınt olduğu söylenebilir. Yine ajans gelirlerindeki merkez-yerel oranına bakıldığında, diğer gelir kalemleri dikkate alınmadan hesaplandığında gelirlerin yaklaşık \%80'inin merkezi yönetimin katkısıyla oluştuğu, yerel payın ise \%20'de kaldığı görülmektedir (Kalkınma Ajanları 2010 Yılı Genel Faaliyet Raporu, 2011: 47-50). Bu durum merkezileşme yerelleşme bağlamında önemli bir veri olarak karşımıza çıkmaktadır.

Tablo 3: Kalkınma Ajanları 2010 Yılı Bütçe Gerçekleşmeleri (Önceki Yıldan Devreden Gelirler Hariç)

\begin{tabular}{|c|c|c|c|c|c|}
\hline Gelirler & Bütçe & Yüzde Pay & Gerçekleşme & Yüzde Pay & Fark \\
\hline Genel Bütçe & $450,000,000$ & 44,428 & $442,643,744$ & 58 & $-7,356,256$ \\
\hline $\begin{array}{l}\text { il Özel } \\
\text { İdareleri }\end{array}$ & $20,987,729$ & 2,072 & $20,094,967$ & 2 & -892762 \\
\hline Belediyeler & 191.582 .854 & 18,915 & 85.488 .428 & 11 & $-106,094,426$ \\
\hline $\begin{array}{l}\text { Sanayi ve } \\
\text { Ticaret } \\
\text { Odaları }\end{array}$ & 4.810 .390 & 0,475 & 5.073 .585 & 1 & 263,195 \\
\hline Diğer Gelirler & 345.479 .417 & 34,11 & 211.528 .455 & 28 & $-133,947,962$ \\
\hline $\begin{array}{l}\text { Gelirler } \\
\text { Toplamı }\end{array}$ & 1.012 .860 .390 & 100.0 & 764.829 .179 & 100 & $-248,031,211$ \\
\hline
\end{tabular}

Kaynak: Kalkınma Bakanlığı Kalkınma Ajanları 2010 Yılı Genel Faaliyet Raporu, Ankara 2011, s.49.

Kalkınma ajanslarının 2012 yılı bütçe gerçekleşmesinin oranı \%53'tür. Oranın bu kadar düşük olmasının nedeni, kalkınma ajanslarına merkezî bütçe gelirlerinden aktarılacak olan 336 milyon TL'nin ajanslara 2013 yılı içinde verilmesidir.

Bu nedenle gelirin önemli bir kısmı 2013 bütçesi içinde yer almaktadır. Gelir gerçekleşmeleri toplamı içinde gelir kalemlerinin oransal dağılımına bakacak olursak; genel bütçe gelirleri \%21,9; il özel idareleri \%7,5; belediyeler \%40,2; sanayi ve ticaret odaları yüzde 1,8 ve diğer gelirler (Geçmiş dönemden devreden gelirler hariç) yüzde 28,6 paya sahiptir. 
Gerçekleşme oranı en yüksek gelir kalemi (\%121) yine en düşük miktara sahip olan sanayi ve ticaret odalarından aktarılan paylardır. İkinci sırada ise 2010 'da en düşük gerçekleşme oranına sahip olan belediyeler (\%120) vardır (Kalkınma Ajansları 2012 Yılı Faaliyet Raporu, 2013: 39). 2012 bütçesindeki merkez-yerel oranı incelendiğinde ise diğer gelirler ve önceki yıldan devreden gelir kalemleri hariç tutulduğunda, merkezi yönetim $\% 31$, yerelden aktarılan paylar ise $\% 69$ 'luk orana sahip olduğu görülmektedir. Ancak burada genel bütçeden aktarılacak payların önemli bir bölümünün 2013 yılında ajanslara verildiğini unutmamak gerekir. Bu durumda, eğer 2013 yılında ajanslara aktarılan 336 milyon TL 2012 yılında aktarılmış olsaydı, ajansların bütçesinde merkezi yönetim \%69, yerelden aktarılan paylar \%31'lik orana sahip olacakt. Mali özerklik kavramına ilişkin yapılan açıklamalar dikkate alındığında, ajans bütçesinin merkezi yönetime bağımlı olması 2012 yılında olduğu gibi gelirin düzensiz şekilde ajanslara aktarılmasına neden olmaktadır. Buda kuşkusuz kalkınma ajanslarının iş ve işlemlerinde, destekledikleri projelerin devamlılığının sağlanmasında aksamalara neden olmaktadır.

Tablo 4: Kalkınma Ajanları 2012 Yılı Bütçe Gerçekleşmeleri

\begin{tabular}{|c|c|c|c|c|c|}
\hline Gelirler & Bütçe & Yüzde Pay & Gerçekleşme & Yüzde Pay & Fark \\
\hline $\begin{array}{l}\text { Genel } \\
\text { Bütçe }\end{array}$ & $450,000,000$ & 63.9 & $81,800,000$ & 21.9 & $-368,200,000$ \\
\hline $\begin{array}{l}\text { II Özel } \\
\text { İdareleri }\end{array}$ & $27,648,685$ & 3.9 & $28,169,554$ & 7.5 & 520,869 \\
\hline Belediyeler & $125,069,186$ & 17.8 & $150,095,641$ & 40.2 & $25,026,454$ \\
\hline $\begin{array}{l}\text { Sanayi ve } \\
\text { Ticaret } \\
\text { Odaları }\end{array}$ & $5,527,851$ & 0.8 & $6,740,892$ & 1.8 & $1,213,041$ \\
\hline $\begin{array}{l}\text { Diğer } \\
\text { Gelirler }\end{array}$ & $95,830,839$ & 13.6 & $107,001,049$ & 28.6 & $11,170,210$ \\
\hline $\begin{array}{l}\text { Gelirler } \\
\text { Toplamı }\end{array}$ & $704,076,562$ & 100.0 & $373,807,136$ & 100.0 & $-330,269,426$ \\
\hline $\begin{array}{l}\text { Önceki } \\
\text { Yıldan } \\
\text { Devreden } \\
\text { Gelirler }\end{array}$ & $908,804,664$ & - & $908,804,664$ & - & 0 \\
\hline $\begin{array}{l}\text { Genel } \\
\text { Toplam }\end{array}$ & $1,612,881,226$ & - & $1,282,611,800$ & - & $-330,269,426$ \\
\hline
\end{tabular}

Kaynak: Kalkınma Bakanlığı, Kalkınma Ajansları 2012 Yılı Faaliyet Raporu, 2013 Ankara, s.39.

2014 yılına ait tablo incelendiğinde kalkınma ajanslarının (Fırat Kalkınma Ajansı hariç) gelirlerinin önemli bir bölümünün merkezi yönetimce sağlandığı görülmektedir. Ajans bütçelerinin \%73'ü genel bütçeden, \%3,2'si il özel idarelerinden, \%22,6'sı belediyelerden ve $\% 1,2$ 'si ise sanayi ve ticaret odalarından aktarılan paylardan oluşmaktadır. Bu anlamda ajans gelirlerinin (diğer gelirler ve geçmiş dönemden devreden gelirler hariç) \%73'ü merkezi yönetimden, \%27'si ise yerelden aktarılan paylardan oluştuğu görülmektedir. 2014 ylIına ait veriler incelenirken iZKA (İzmir Kalkınma Ajansı)'nın merkezi yönetim bütçesinden hiç pay almadığı görülmüştür. 
Bu durum ajans bütçesinde yaklaşık \%20, ajans gelir kalemlerinde (merkezi yönetim bütçesinden aktarılan pay, il özel idaresinden aktarılan pay, belediyelerden aktarılan paylar, sanayi ve ticaret odalarından aktarılan paylar) ise yaklaşık \%30'luk bir azalmaya neden olmuştur (İzmir Kalkınma Ajansı 2014 Faaliyet Raporu: 20). Bu durum ajans gelirler kalemlerinden genel bütçe kaleminin ne derece önemli olduğunu kanıtlar niteliktedir. Kalkınma ajanslarının aldığı kararları uygulayabilmesi için mali anlamda özerkliğe sahip olması gerekmektedir. Ancak 2010, 2012, 2014 yıllarına ait tablolar incelendiğinde ajans bütçelerinin büyük oranda genel bütçeden yani merkezi yönetimden aktarılan kaynaklara bağımlı olduğu görülmektedir. Bu bağımlılık 2012 yılında olduğu gibi, kaynak tahsisinde yaşanan gecikmeler dolayısıyla ajansların finanse ettiği projeleri aksama tehlikesi ile yüz yüze bırakmaktadır. Bu durumda ajansların gelir kalemleri içinde yer alan yerel yönetimlerin, kendi mali yapılarını olumsuz etkilemeyecek biçimde, paylarının arttırıması ve ajansların kendi kaynaklarını yaratmak konusunda daha etkin çalışma yapmaları hizmetlerin etkinliği ve verimliliği açısından faydalı olacaktır.

Tablo 5: Kalkınma Ajanları 2014 Yılı Bütçe Gerçekleşmeleri²

\begin{tabular}{lll} 
Gelirler & Gerçekleşme & Yüzde Pay \\
\hline Genel Bütçe & $430.353 .825,00$ & 73 \\
II Özel İdareleri & $18.644 .579,62$ & 3,2 \\
Belediyeler & $132.989 .606,20$ & 22,6 \\
Sanayi ve Ticaret Odaları & $6.701 .143,91$ & 1,2 \\
Gelirler Toplamı & $588.689 .154,73$ & 100
\end{tabular}

Kaynak: 2014 yılına ilişkin tablo, 25 adet (Fırat Kalkınma Ajansı hariç) kalkınma ajansının 2014 yılı faaliyet raporlarından yazarlar tarafindan derlenmiştir.

\subsection{Kalkınma Ajanslarının İş ve İşlemlerinin Merkezileşme-Yerelleşmeye Etkisi}

Kalkınma ajanslarının iş ve işlemlerinin merkezileşme-yerelleşme boyutuyla değerlendirilmesi, Kalkınma Bakanlığı'nın ajanslar üzerindeki vesayet denetimi ya da Kalkınma Bakanlığının, ajanslar ile ilgili görevleri olarak adlandırılabilir. Vesayet denetimi kısaca yerel yönetimlerin merkezi yönetimce denetlenmesi olarak ifade edilebilir. Başka bir deyişle, devlet tüzel kişiliği dışında yer alan kuruluşların genel ve yerel menfaatleri korumak için merkezi idare ya da merkezi idarenin taşradaki temsilcisi tarafindan denetlenmesidir (Kalabalık,2005: 728-729). Merkezi idarenin kendi içinde uyguladığı hiyerarşik denetimden farklı olarak, bu yetkinin kullanımı, sınırları ve kullanacak makam kanun ile belirtilmelidir. Kalkınma Bakanlığı'nın ajanslar üzerindeki önemli bir yetkisi çalışma programının belirlenmesidir.

Çalışma programı bakanlığın belirlediği usullere uygun olarak "bütçe yılına ilişkin öncelik alanlarını, tedbirleri, proje ve faaliyetleri ve bunlara ayrılacak tahmini malî kaynakları ve bunların Ajans bütçesi içindeki tahmini oranı ile belirtilen faaliyetlerin gerekçelerini" içerecek şekilde ajans genel sekreterince hazırlanır.

22014 yılına ilişkin tablo, 25 adet (Fırat Kalkınma Ajansı hariç) kalkınma ajansının 2014 yılı faaliyet raporlarından yazarlar tarafindan derlenmiştir. Ajansların faaliyet raporlarındaki farklılıklardan dolayı, diğer yılların aksine yalnızca bütçe gerçekleşme rakamları (diğer gelirler ve önceki yıllardan devirler hariç) hesaplanmıştır. 
Hazırlanan çalışma programı önce yönetim kurulunun kabulüne ve sonra bakanlığın onayına sunulur (Kalkınma Ajansları Bütçe Ve Muhasebe Yönetmeliği, m.21). Böylelikle çalışma programı hem merkezi yönetimin taşra teşkilatının başında yer alan valinin başkanı olduğu yönetim kurulunca hem de merkezi yönetimin başkent teşkilatında yer alan bakanlıkça onaylanmış olmaktadır.

Kalkınma ajanslarının bütçe kalemleri içinde merkezi yönetimin var olan ağırlığı daha önce ifade edilmişti. Ayrıca kalkınma ajanslarının bütçelerinin hazırlanması aşamasında da bakanlığın önemli yetkileri mevcuttur. Ajansların bütçeleri genel sekreter tarafindan hazırlanır ve yönetim kurulu tarafindan onaylanır. Daha sonra ise görüş alınmak üzere çalışma programı ile birlikte Kalkınma Bakanlığına gönderilir (5449 sayılı Kanun, md.11,14,23). Kalkınma Bakanlığı çalışma programı ve bütçe arasında bir uyumsuzluk görürse, bütçeyi düzeltilmesi için ajansa geri gönderebilmektedir. Dolayısıyla bu durum bir "de facto onay sistemi" olarak ifade edilebilir. Bunun dışında yasada ajansların gelirleri sayılırken ifade edilen genel bütçe vergi tahsilatlarından aktarılacak transfer ödeneği konusunda da bakanlığın önemli bir yetkisi vardır. Bu transfer ödeneği bakanlık bütçesi içinde yer almakta, transferin tavanı ve aktarılacak pay ise Yüksek Planlama Kurulunca (Başbakan, Kalkınma Bakanı ve belirlenen diğer Bakanlardan oluşur) belirlenmektedir. Yasada gelir kalemlerinin ve payların bu kadar açık şekilde belirtilmesi mali özerklik adına önemli bir adım olarak görülse de, uygulamada durum bunun tam tersini yansıtmaktadır. Örneğin 2014 yılı için ajanslara 1,5 milyar TL kaynak aktarılması gerekirken, sadece 450 milyon TL aktarılmıştır. Ayrıca bu payın nasıl dağıtılacağı ve ödeneklerin serbest bırakılması konusunda da Kalkınma Bakanlığı yetkilidir (Karasu, 2015: 279). Dolayısıyla yasada mali özerklik adına önemli adımlar atımış olsa da, merkezi yönetim kuruluşlarına verilen yetkiler dolayısıyla ajansların gelir kaynaklarının önemli bir kısmında kesintiler yaşanmaktadır.

Kalkınma bakanlığı ve ajanslar arasındaki ilişkinin bir örneği de proje ve destek konularında görülmektedir. Buna göre bakanlık tarafindan hazırlanan Destek Yönetimi Kılavuzu ve Proje Uygulama Rehberi'ne ajanların uyması gerektiği yönetmelikte belirtilmiştir (Kalkınma Ajansları Proje Ve Faaliyet Destekleme Yönetmeliği, m.4). Ayrıca Bakanlık ajansların destekleyeceği proje alanlarını denetleyerek, çalışma programlarında yer almayan alanların desteklenmesini engelleyebilmektedir. Bunun yanında güdümlü proje desteği verilmesi konusunda da proje maliyeti 5 milyon TL ve üzerinde olan projeler için bakanlık onayı gerekmektedir. Bütçesi 5 milyon TL'nin altında olan güdümlü projeler ise, çalışma programları bakanlık tarafindan denetlendiği için bu yolla denetlenmektedir (Karasu, 2015: 279). Kalkınma Ajansları, ifade ettiğimiz bütün bu ağır vesayet denetiminin yanında, Bakanlıkça gerçekleştirilen Mali Yönetim Yeterliliği denetimine de tabidir. Bu denetim çeşitli bakanIıklarda görevli bürokratların oluşturduğu Mali Yönetim Yeterlik Komisyonunca beş yılda bir veya bakanlığın gerekli gördüğü hallerde re'sen yapılabilir. Kurul tarafindan oluşturulan rapor bakanlıkça karar bağlanır. Bu karar ajansın mali yönetim yeterliğini kaybettiği yönünde olur ise, ajansın proje ve faaliyet destekleri için kaynak kullanımı ve bu amaçla bakanlık bütçesinden aktarılacak olan transfer ödeneğinin kullanılması engellenir (Kalkınma Ajansları Denetim Yönetmeliği, md.4,5). Dolayısıyla ajansların amaçlarını gerçekleştirebilmesi, Kalkınma Bakanlı̆ı̆ın iznine tabidir demek yanlış olmayacaktır. Kalkınma Bakanlığı ve Kalkınma ajansları arasındaki ilişkiye ilişkin yapılan açıklamalar incelendiğinde, bakanlığın kanunun 4. Maddesi ile kendisine verilen koordinasyon görevinin çok ötesinde yetkilere sahip olduğu görülecektir. 
Ajanslar için düzenlenen ikincil mevzuat uygulamada birçok konunun bakanlık onayı ile gerçekleştirilmesini gerekli kılmıştır. Bu durum ajansların esnek ve hızlı karar almalarını ve hesap verebilirliğini olumsuz etkilemektedir (Devlet Denetleme Kurulu, Türkiye'nin Kalkınma Ajansları Uygulamasının Değerlendirilmesi (Hizmete Özel), 2014: 796). Diğer taraftan, bölgesel kalkınmanın sağlanmasında gerekli olan özerkliği de zedelemektedir.

\section{SONUÇ}

Dünyada klasik kamu yönetimi anlayışından yeni kamu yönetimi anlayışına doğru yaşanan değişim ve tek aktörlü yönetim anlayışından çok aktörlü yönetişim anlayışına geçiş, yeni kurumsal yapıların ortaya çıkmasına neden olmuştur. Özellikle merkezi yönetim kurumlarının hantal, bürokratik ve verimsiz olarak tanımlandığı 1980'lerde yerelleşme giderek önem kazanmaya başlamış, eskinin kurumlarının yerine esnek, katılımcı, etkin ve verimli kurumlar oluşturulması fikri desteklenmiştir. Bu süreçler içinde kalkınma anlayışı da değişikliğe uğramış, yeni bölgesel kalkınma anlayışı küreselleşme, neo-liberalizm ve post-fordizm çerçevesinde şekillenmiştir. İşte hem yeni bölgesel kalkınma anlayışının ortaya çıkması hem de yeni kurumsal yapılara duyulan ihtiyacın belirmesi kalkınma ajanslarının teorik zemininin ortaya çıkmasına neden olmuştur.

Günümüzde sayıları giderek artan yerel/bölgesel yönetim kurumları ile merkezi yönetim kurumları arasında görev ve kaynak bölüşümü sorunları yaşanmaktadır. Merkezi yönetim güçlerinin temelini oluşturan kaynak dağıtımı tekelini kendi lehlerine olacak şekilde biçimlendirme gayretinde iken, yerel kuruluşlar ise yerindenlik ilkesi gereği etkin ve verimli hizmet sunumunun ancak kendilerince gerçekleştirilebileceğini iddia etmektedir. Merkezileşme-yerelleşme ikilemi olarak adlandırabileceğimiz bu durum günümüz Türkiye'sinde özellikle kalkınma ajansları üzerinde giderek daha belirgin bir hal almaktadır.

Kalkınma ajanslarının 2006'da kurulmaya başlamalarından itibaren Türkiye adına hem kalkınma anlayışında hem de yönetim kültüründe bir yeniliği ifade ettikleri bir gerçektir. Bu anlamda kendine özgü yapıya sahip olmaları, kamu-özel-sivil ortaklığını yansıtmaya çalışmaları ve kendilerine ait mali kaynaklarının bulunması ajansların daha dikkat çekici bir hal almasına neden olmuştur.

Kalkınma ajanslarının idari yapısına ilişkin açıklamalar incelendiğinde, kalkınma kurulu ve yönetim kurulu arasındaki iletişimin eksik olduğu sonucuna varılabilir (Görmez ve Eroğlu, 2013: 17). Yılda iki kez toplanan ve bir danışma organı olan kalkınma kurulunun vali ve belediye başkanlarının yer aldığı yönetim kurulunun politikalarını ne derece etkileyeceği bir büyük bir sorun olarak karşımızda durmaktadır.

Türkiye'de istihdamın sektörel dağılımı incelendiğinde 2013 yılı itibariyle hizmet sektörü $\% 50$, sanayi sektörü $\% 26,4$ ve tarım sektörünün $\% 23,6$ paya sahip olduğu görülmektedir. Tarım sektörünün TR33 (Manisa, Afyonkarahisar, Kütahya, Uşak), TR82 (Kastamonu, Çankırı, Sinop), TR83 (Samsun, Tokat, Çorum, Amasya), TR90 (Trabzon, Ordu, Giresun, Rize, Artvin, Gümüşhane), TRA1 (Erzurum, Erzincan, Bayburt), TRA2 (Ağrı, Kars, Iğdır, Ardahan), TRB1 (Malatya, Elazı̆̆, Bingöl, Tunceli) bölgelerinde \%40'ın üzerinde bir ağırlığa sahip olduğu düşünüldüğünde ajansların üye yapısıyla ilgili önemli bir sorunun varlığına işaret edilebilir (TÜiK, Hanehalkı İ̧̧ücü Araştırması Bölgesel Sonuçlar 2004-2013: 14). Bu sorun kalkınma ajanlarının karar organı olan yönetim kurullarında tarım sektörünü temsil edecek bir üyenin bulunmamasıdır (Cankorkmaz, 2011: 131). 
Tek ilden oluşan ajanslarda bu durum kalkınma kurullarınca seçilen üyelerle aşılabilecekken, birden çok ili kapsayan ajanslarda bu durum önemli bir problem olarak yerini korumaktadır. Ayrıca tek ilden oluşan ajanslarda da, tarım sektörünü temsil eden üyelerin bakanlar kurulunca kalkınma kuruluna dahil edilip edilmeyeceği bir sorun alanı olarak ifade edilebilir. Yukarıda söz edilen olumsuz durum sadece tarım sektörü için geçerli değildir. Örneğin turizm sektörü açısından gelişmiş olan Antalya ilinin yer aldığı Batı Akdeniz Kalkınma Ajansı (BAKA) ve Muğla ilinin yer aldığı Güney Ege Kalkınma Ajansı (GEKA) yönetim kurullarında bu sektörü temsil edecek bir üye bulunmamaktadır. Bu anlamda sadece danışma işlevi gören kalkınma kurulda yer alan tarım ve turizm sektörü temsilcilerinin ajans politikalarını ne derece etkileyebileceği tartışılmaya değer bir konudur.

Ajansların idari yapısı dışında mali yapısı konusunda da önemli sorun alanları mevcuttur. Bunların başında ajans gelirleri içinde merkezi yönetim payının ağırlığı gelmektedir. Ayrıca merkezi yönetimce sağlanan bu kaynakların dağıtımı ve tahsilatı konusunda da çeşitli problemler yaşanmaktadır. Bu durum mali özerkliği zedeleyici bir yapıya işaret etmektedir. Ajanslar kendi gelirlerini oluşturamaz ve yereldeki kuruluşlardan yeterli destek göremezler ise merkeze olan mali bağımlılık devam edecektir. Bu çerçevede ajansların kuruluş felsefesinde sapmalar meydana gelecektir.

Kalkınma ajanslarının temel sorun alanlarından biride iş ve işlemleri üzerinde Kalkınma Bakanlığı'nın vesayetidir. Yasada Bakanlık ajanslar arasında koordinasyon görevi ile görevlendirilmişken, özellikle ikincil mevzuatın oluşturulması ile birlikte koordinasyondan vesayete doğru bir görevi yerine getirmeye başlamıştır (Devlet Denetleme Kurulu, Türkiye'nin Kalkınma Ajansları Uygulamasının Değerlendirilmesi (Hizmete Özel), 2014: 796). Bakanlığın koordinasyonu aşacak şekilde çeşitli işlemler, bütçe ve atamalar için onaya varan yetkilere sahip olması hem ajansların özerkliğini zedelemekte hem de ajanların temel ilkeleri içinde yer alan yönetişim felsefesi ile çatışmaktadır.

Kalkınma Bakanlığı ve kalkınma ajansları arasındaki koordinasyonu aşan ilişkinin yanında, ajans teşkilat yapısı içinde valinin yönetim kurulu başkanı olması, klasik kamu yönetimi anlayışından gelen alışkanlıkla, merkezi yönetimin yerelde bulunan unsurlarının kendilerini yerel ve bölgesel kalkınma konularında ana unsur olarak görmelerine neden olmaktadır (Gül vd., 2014: 274). Yine bunun yanında tek ilden oluşan ajanslar dışında ajans yönetimlerinin kamu-özel-sivil ortaklığını tam olarak yansıtacak şekilde kurulmaması da ajansların mali kaynaklarının büyük bir bölümünün kamu kaynaklarından oluşmasının bir sonucu olarak görülebilir (Göymen, 2010: 161). Bu durum 2014 yılında Devlet Denetleme Kurulu raporunda da ajansların "merkezin taşradaki aracı kurumu" olarak algılanmaya ve yeni kamu yönetiminden klasik kamu yönetimi anlayışına evrilme tehlikesi ile karşı karşıya olduğu şeklinde ifade edilmiştir (Devlet Denetleme Kurulu, Türkiye'nin Kalkınma Ajansları Uygulamasının Değerlendirilmesi (Hizmete Özel), 2014: 798). 2006 yılında kabul edilen 5449 sayılı Kalkınma Ajanslarının Kuruluş, Koordinasyon ve Görevleri Hakkında Kanun'un 10. yılında ajansların henüz istenilen seviyede bir gelişme geçekleştirdikleri söylemek oldukça güçtür. Bu durumun hem bölgesel kalkınma hem de bölgesel yönetişimin geliştirilmesi konularında var olduğu ifade edilebilir. Kalkınma ajanslarında yaşanan sorunların giderilmesi için ajanların yeniden yapılandırılması, kalkınma kuruluna daha fazla yetki verilmesi, yönetim kurulu üyeliklerinin her bölge için bölgenin başat sektörlerine göre ayrı ayrı belirlenmesi ve ajansların mali olanaklarını geliştirici önlemlerin alması gerekmektedir. 


\section{KAYNAKÇA}

Akgül, B. (2010), Türkiye'de Kalkınma Ajanslarının Örgütsel Yapısının Analizi ve Yeniden Yapılanma Önerileri. Birol Akgül, Nıfset Uzay (Ed.), Türkiye'de Bölgesel Kalkınmanın Yeni Örgütleri Kalkınma Ajansları içinde. Bursa: Ekin.

Bayramoğlu, S. (2010). Yönetişim Zihniyeti Türkiye'de Üst Kurullar ve Siyasal iktidarın Dönüşümü (2. Baskı). İstanbul: iletişim.

Berber, M., Çelepçi, E. (2005). Türk Bölgesel Kalkınma Politikalarında Yeni Arayışlar: Kalkınma Ajansları ve Türkiye'de Uygulanabilirliği, Harun Terzi (Ed.), Karadeniz Bölgesel Kalkınma Sempozyumu Bildiriler Kitabı içinde. 13-14 Ekim 2005, Trabzon, 146-155.

Cankorkmaz, Z. (2011). Türkiye'de Bölgesel Kalkınma Ajansları ve Bu Ajanslara Yönelik Eleştiriler. Dokuz Eylül Üniversitesi Iktisadi ve Idari Bilimler Fakültesi Dergisi, 26 (1), 113-138.

Cihangir Çamur, K., Gümüş, Ö. (2005). İstatistiki Bölge Birimleri (NUTS Sistemi). Menaf Turan (Der.), Bölge Kalkınma Ajansları Nedir, Ne Değildir? içinde. Ankara: Paragraf.

Çevik, H. H. (2012). Kamu Yönetimi Kavramlar-Sorunlar-Tartş̧malar (2. Baskı). Ankara: Seçkin.

Derdiman, R. C. (2007). İdare Hukuku (2. Baskı). Bursa: Alfa Aktüel.

Devlet Planlama Teşkilat. (2000). Sekizinci Beş Yılık Kalkınma Planı Bölgesel Gelişme Özel ihtisas Komisyonu Raporu, Ankara.

Efe, A. (2016). Devlet Denetleme Kurulu Raporunda Belirtilen Kalkınma Ajansları Sorunları Üzerinden COSO Ve COBIT Standartlarına Göre Kök Neden Analizleriyle Çözümleme, Bilgi Ekonomisi ve Yönetimi Dergisi, 11 (1), 107-124.

Emini, F. T., Görün, M. (2013). Türkiye'de Faaliyet Gösteren Bölgesel Kalkınma Ajanslarının Misyon ve Vizyon Bildirimlerinin Analizi. Mustafa Ökmen, Güven Şeker, Fatih Yaman (Der.), Küreselleşme-Yerelleşme Sarmalında Kalkınma Ajansları- Yapılar, Sorunlar ve Çözüm Arayışları içinde. Ankara: Orion.

Eroğlu, H. (1974). İdare Hukuku Dersleri. Ankara: Sevinç.

Eryılmaz, B. (2007). Kamu Yönetimi: Düşünceler, Yapılar, Fonksiyonlar, İstanbul: Erkam.

Giritli, I., Bilgen, P., Akgüner, T. (2008). İdare Hukuku (2. Basım). İstanbul: Der.

İzmir Kalkınma Ajansı. (2014). IZKA 2014 Yılı Faaliyet Raporu,

http://izka.org.tr/files/2015/faaliyetraporu.pdf, (Erişim Tarihi: 25 Ekim 2015)

Görmez, K., Eroğlu, H. T. (2013). Köycülükten Toplum Kalkınmasına, Köykentlerden Kalkınma Ajanslarına Yerel Kalkınma Serencamımız: Bir Zihniyet Analizi. Mustafa Ökmen, Güven Şeker, Fatih Yaman (Der.), Küreselleşme-Yerelleşme Sarmalında Kalkınma AjanslarıYapılar, Sorunlar ve Çözüm Arayışları içinde. Ankara: Orion.

Göymen, K. (2010). Türkiye'de Yerel Yönetişim ve Yerel Kalkınma. İstanbul: Boyut.

Gözler, K., Kaplan G. (2012). İdare Hukukuna Giriş (16. Baskı). Bursa: Ekin.

Gözübüyük, Ş. (2006). Türkiye'nin Yönetim Yapısı (9. Baskı). Ankara: Turhan.

Gül, H., Kiriş, H. M., Negiz, N., Gökdayı, I. (2014). Türkiye'de Yerel Yönetimler ve Yerel Siyaset. Ankara: Detay. Güler, B. A. (2011). Türkiye'nin Yönetimi (3. Baskı). Ankara: Imge.

Günday, M. (2002). İdare Hukuku (6. Basım). Ankara: İmaj.

Güney Marmara Kalkınma Ajansı. (2009). GMKA 2009 Yılı 2. Olağan Kalkınma Kurulu Toplantısı Sonuç Bildirgesi,

http://www.gmka.org.tr/uploads/downloads/dosya/kalkinma_kurulu_toplanti/2009/2.\%20 kalk\%C4\%B1nma\%20kurulu\%20tutana\%C4\%9F\%C4\%B1.pdf, (Erişim Tarihi: 20 Ekim 2015)

Kalabalık, H. (2005). Avrupa Birliği Ülkeleriyle Karşılaştırmalı Yerel Yönetim Hukuku Teori-Uygulama. Ankara: Seçkin.

Kalkınma Ajansları Bütçe Ve Muhasebe Yönetmeliği, Resmi Gazete Tarihi: 28.09.2006, Resmi Gazete Sayıs: 26303, https://kms.kaysis.gov.tr/Home/Goster/37669, (Erişim Tarihi: 22 Ekim 2015)

Kalkınma Ajansları Denetim Yönetmeliği, https://kms.kaysis.gov.tr/Home/Goster/39158, (Erişim Tarihi: 18 Ekim 2015) 
Kalkınma Ajansları Proje Ve Faaliyet Destekleme Yönetmeliği, Resmi Gazete Tarihi: 08.11.2008 Resmi Gazete Sayısı: 27048, https://kms.kaysis.gov.tr/Home/Goster/38725, (Erişim Tarihi: 19 Ekim 2015)

Kalkınma Bakanlığı. (2011). Kalkınma Ajanları 2010 Yılı Genel Faaliyet Raporu, Ankara.

Kalkınma Bakanlığı (2013). Kalkınma Ajansları 2012 Yılı Faaliyet Raporu, Ankara.

Kalkınma Bakanlığı. (2014). Bölgesel Gelişme Ulusal Stratejisi (2014-2023), Ankara.

Karasu, K. (2009). Yeni Bir Tür Merkezileşmenin Aracı Olarak Bölge Kalkınma Ajansları, Memleket Mevzuat, 4 (46), 24-33.

Karasu, K. (2009). Yerelleşme Söylemi ve Bölge Kalkınma Ajansları, Memleket Siyaset Yönetim, 4 (11), 1-43.

Karasu, K. (2015). Kalkınma Ajansları: "Modelimi Kaybettim Hükümsüzdür” (Ölçek Siyasetinin Yerelliği), Ankara Üniversitesi SBF Dergisi, 70 (2), 273-316.

Kayasü, S., Pınarcıoğlu, M., Yaşar, S. S., Dere, S. (2003). Yerel/Bölgesel/Ekonomik Kalkınma Ve Rekabet Gücünün Artırılması: Bölgesel Kalkınma Ajansları. İstanbul: İstanbul Ticaret Odası.

Ökmen, M., Parlak, B. (2000). Kuramdan Uygulamaya Yerel Yönetimler (2. Baskı). Bursa: Alfa Aktüel.

Öncel, S. Y. (1998). Mahalli Idareler Maliyesi. İstanbul: Filiz.

Özer, M. A. (2012). Türkiye'de Bölgesel Kalkınma Ajanslarının Sosyal Ekonomik İşlevleri, Kamu-IŞ, $12(2), 37-74$.

Özer, Y. E. (2007). Küresel Rekabet-Bölgesel Kalkınma Ajansları ve Türkiye, Review of Social, Economic \& Business Studies, 9 (10), 389-408.

Özmen, F. (2008). AB Sürecinde Türkiye'de Bölgesel Kalkınma Ajanslarının Karşılaşabilecekleri Temel Sorun Alanları, Süleyman Demirel Üniversitesi Iktisadi ve Idari Bilimler Fakültesi Dergisi, 13 (3), 327-340.

Parlak, B. (2014). Avrupa Birliği Perspektifinden Merkezi Yönetim - Yerel Yönetim İlişkileri, TESAM Akademi Dergisi, 1, 7-40.

Resmî Gazete, Bakanlar Kurulu Kararı, 25 Temmuz 2009 Cumartesi, Sayı: 27299, http:// www.resmigazete.gov.tr/main.aspx?home=http://www.resmigazete.gov. tr/eskiler/2009/07/20090725.htm\&main=http://www.resmigazete.gov.tr/ eskiler/2009/07/20090725.htm, (Erişim Tarihi: 20 Ekim 2015)

Sert, O. (2012). Bölge, Türkiye'de Bölge Kavramı ve Kalkınma Ajanslarının Yapısı, Sosyal Bilimler Dergisi, 2 (4), 119-146.

Şinik, B. (2010). Anayasa Mahkemesi Kararı Işığında Türkiye'de (Bölge) Kalkınma Ajansları, Megaron, 5 (3), 128-136.

Tek Turan, H. (2013). Yönetişim ve Yeni Kamu Yönetimi. Fatma Neval Genç (Der.), Yönetişim Türk Kamu Yönetimine Yansımaları içinde. Konya: Çizgi.

T.C. Cumhurbaşkanlığı Devlet Denetleme Kurulu. (2014). DDK Araştırma Ve inceleme Raporu: Türkiye'nin Kalkınma Ajansları Uygulamasının Değerlendirilmesi (Hizmete Özel),

https://www.tccb.gov.tr/assets/dosya/20140130-2014-03.PDF, (Erişim Tarihi: 21 Ekim 2015)

Tüik, Hanehalkı İşgücü Araştırması Bölgesel Sonuçlar 2004-2013, http://www.tuik.gov.tr/jsp/ duyuru/upload/yayinrapor/HIA_2013.pdf, (Erişim Tarihi: 20 Ekim 2015)

Toksöz, F. (2008). İyi Yönetişim El Kitabı, İstanbul: TESEV.

Tortop, N. (1996). Yerel Yönetimler Maliyesi (Görev ve Kaynak Bölüşümü). Ankara: TODAiE.

Tortop, N., Aykaç, B., Yayman, H., Özer, M. A. (2008). Mahalli Idareler (2. Basım). Ankara: Nobel.

Tutar, F., Demiral, M. (2007). Yerel Ekonomilerin Yerel Aktörleri: Bölgesel Kalkınma Ajansları, Eskişehir Osmangazi Üniversitesi iiBF Dergisi, 2 (1), 65-83.

Yılmaz, B. (2011). Bölgesel Politikaların Tarihsel Gelişimi ve Yeni Bir Model Olarak Kalkınma Ajansları, Akademik Fener, 15, 29-41.

5449 sayılı Kalkınma Ajanslarının Kuruluş, Koordinasyon ve Görevleri Hakkında Kanun, http:// www.mevzuat.gov.tr/Metin.Aspx?MevzuatKod=1.5.5449\&sourceXmISearch=\&Mevzuatll iski=0, (Erişim Tarihi: 20 Ekim 2015) 